\title{
A faca não corta o Fogo e Ofício Cantante, de Herberto Felder
}

\author{
Mauricio Salles Vasconcelos \\ Universidade de São Paulo
}

epois de editado no Brasil Ou o poema contínuo, a suma, até então, mais recente da produção de Herberto Helder, sua Poesia Toda - como foi nomeada uma reunião possível do conjunto, primeiramente em 1973 e depois em 1990) -, a edição de um título à parte como $A$ faca não corta o fogo, em Portugal, no final de 2008, suscitou imenso, imediato interesse de um público cada vez mais numeroso, cultuador desse, para muitos, autor central da lírica escrita em português. Rapidamente esgotado, o último livro de Helder se tornou obra rara negociada em leilões a preços altíssimos. No Brasil, o poeta paulista Marcelo Ariel deu notícia em seu blog - teatrofantasma.blogspot.com - da impossibilidade de se obter esse título prontamente desaparecido do mercado tão logo foi lançado. Destacando-lhe alguns versos, Ariel pôde depor sobre a aura que cerca o autor arredio a publicidade e a prêmios, cada vez mais concentrado numa escrita construída como um foco volitivo em torno de uma topologia básica, eivada de telurismo e orbitada ao redor de corpo e cosmo. Escrita aberta, porém, à mescla e à diversidade do tempo, como se pode depreender da reposição e renovação crescentes contidas no projeto Ou o poema contínuo, que subjaz à publicação de livros escritos ao lado e no interior do tomo total, frequentemente retomado.

Foi o que ocorreu no início de 2009, com a edição de Ofício cantante, a mais nova súmula helderiana, trazendo o cobiçadíssimo volume $A$ faca não corta o fogo, desde já um marco na poesia produzida em língua portuguesa, observando-se o que se refere às estratégias de mercado e à recepção centrada numa espécie de raro culto à volta de um poeta na cena cultural contemporânea, como também o que concerne ao espaço de escrita elaborado por HH. Pois, em sua leitura, trava-se contato com um instante de culminância de um processo textual já 
conhecido e, também, de choque, com o irrompimento de circuitos criativos insuspeitados. Pode-se até mencionar sobre A faca não corta o fogo uma insurgência vivencial, notando-se a realização de um poemato (como frisa um dos títulos de $\mathrm{HH}$ ) performado em torno do seu fim humano, da proximidade de um encerramento no que se relaciona à poesia toda, à altura dos explicitados 77 anos do autor no tempo em que escrevia alguns dos versos (já que se fechou em 2009 o ciclo septuagenário de sua existência). "setenta e sete de morte e teoria:/ o acesso à música, o rude júbilo, o poema destrutivo (Helder, 2009: 549).

O corpo e a obra já se integravam, através de um entrelaçamento nada simplificador, em versos feitos ao longo de cinqüenta anos de produção. Em Photomaton \& Vox, p. ex, observáveis são os biografemas mixados ao propósito construtivo-cinemático erguido por Helder em um de seus livros mais heterodoxos e, também, mais admirados. Nesse volume é possível ser apreendida, inclusive, uma poética (explicitada de modo inédito pelo autor).

No gesto mesmo em que se configura uma escrita comprometida com o acontecimento, com sua fixação na página à maneira de um ato plástico e nomeador, um feixe de consonâncias colhidas tanto nas artes visuais quanto cênicas na busca do acaso, do aleatório e da fisicidade de traços, promove modos novos de compor e conceber linhas/formas poemáticas. Evidencia-se de modo mais declarado, a partir de Photomaton \& Vox, que a autoposição da linguagem não está distanciada de um movimento descentralizador do escrito em recorrências visuais, sonoras, performativas, sempre inusitadas. Muito ao contrário, o sentido de uma poética pode ser especulado, posto em primeiro plano, quanto mais se indeterminam a disposição e o espaçamento da palavra na longa pauta de um poema contínuo, por força de um ritmo intermitente, guiado pela faixa gravitacional de imagens incessantes, como que imantadas a uma dinâmica que se norteia pelo paroxismo e pela confluência de motivos em retorno, em repetição.

A faca não corta o fogo consolida e extremiza uma série de procedimentos conhecidos e em constante condensação. É como se, a exemplo de alguns produtores de arte essenciais, em atividade entre um e outro milênio, caso de Alain Resnais, no cinema, e da banda musical novaiorquina Sonic Youth, o núcleo das motivações fundamentais fosse alcançado no instante de maior liberação e desprendimento.

Photomaton/Cinematismo - Como ocorre no filme mais recente de Resnais, Herbes folles (2009), a seqüência obsedante de Providence (1978), em que 
a câmera persegue um fragmento da natureza, o oco de uma floresta, de modo gradativo e intensificado, encontra agora sua variação mais reveladora. Lançando-se, por experiência e risco, à incursão vertiginosa pela paisagem, pelo signo-terra, Herbes folles sublinha ainda mais o poder de inquietação, de sugestão, submerso nas imagens anteriores, aquelas de Providence (porque é em torno do lastro das imagens formadoras, do seu potencial simultâneo de aleatoriedade e conhecimento, que o diretor concebe o cinema), com todo seu empenho de busca, de desbravação.

Vox - Em The Eternal, cd de 2009 do Sonic Youth, mais abrangentes, altissonantes, se tornam a musicalidade e o projeto do grupo, embasado numa estética do ruído e da distorção elevados ao ponto máximo de atrito entre um quarteto de guitarras e a bateria. À medida que a banda avança no tempo, desde a segunda metade da década de 1970, mais depurado se mostra o propósito de composição a contar das células de estridência extraídas do instrumental eletrônico (tendo a microfonia como divisa e pauta). Tudo se reativa - o grupo retorna com uma voltagem sonora mais possante - no instante em que o amadurecimento dos músicos consegue erguer a dissonância em derivações sugestivas, contemplativas, nas quais o cume do ruído é conduzido a texturas de pura vibração e harmonia. Em termos de linguagem musical, é como se a cavalgada contivesse o embalo, produzindo o ritornelo de micropartículas composicionais em meio a uma avalanche de guitarras, no centro de um verdadeiro despenhadeiro de percussões executadas pela bateria.

Admirador da música contemporânea, HH não se encontra nada distante dessa maximização de sonoridade saturada, a um só tempo texturada por núcleos de pura ressonância, pelos espaços dados ao silêncio a partir do vibrato prolongado dos efeitos. Algo acontece muito além da moldura rocker e do formato-canção, uma vez que a emissão do canto se combina com a fala, com a dicção própria da poesia. Não se deve omitir a proximidade dos componentes do Sonic Youth com autores literários norte-americanos importantes como Burroughs, John Cage, Patti Smith (aliás, já homenageados por Helder em seus textos) e Corso.

Sempre em revisita, refeitura e acréscimo, o conjunto da obra completa de Herberto Helder toma, em sua versão mais nova, uma feição bem particular outra apresentação do rosto (mencionando-se aqui um título anterior suprimido pelo poeta) - com a inclusão de A faca não corta o fogo em seu corpus. O chama- 
do ao estado nascente das palavras, das imagens, usual em toda sua produção, como se agudiza agora, a contar de 2009 (ano da publicação de Ofício cantante), considerando-se a clareza que tem para Helder o inacabamento da linguagem (reforçado pela curvatura finita da obra/autoria no decurso temporal) quanto mais a assunção criativa, tomada sob uma base mítica (concentrada em fogo), se deixa enunciar.

Pode-se dizer que a elementaridade do fogo, combinada com os signos da corporalidade e da terra, acentua a precisão objetual da faca, não conduzindo, no entanto, a uma estética do menos, bem conhecida em nossa língua através de João Cabral - um autor, aliás, marcante na imponente lírica portuguesa (de Sophia a O’Neill, de Fiama a Silvina), mesmo em Helder, praticante de uma linguagem levada ao avesso da contenção. Mantém-se ele, porém, em certo diálogo de dimensões construtivas, sediadas na sondagem da terra e do território, assim como abertas à concreção, à efetividade matérica das formas plásticas (tão caras ao poeta de Um cão sem plumas). Acrescem-se ao repertório basilar, telúrico (desdobrado nas acepções do ofício, da artesania, resumidas em volta de faca), em uma formulação muito singular, as reiteradas nominações da divindade, da sexualidade e da técnica. Tudo o que dimensiona, enfim, a peculiaridade da poesia helderiana no contexto das literaturas em língua portuguesa, justamente pelo acento reiterado de sua genealogia polimorfa, feita de desmedida violentação verbal, acaba por se mostrar no presente livro, sem amarras, em extrema disseminação, em crescente abertura, errância e elaborado estado de plasmação. "a cálculo lírico infundido nas lides de ar e fogo, / edoi lelia doura/ que o mênstruo coza e a seda escume," (HELDER, 2009: 537).

A faca não corta o fogo. O lance presente de dados não abole, complexifica o acaso, sem resultar na poesia tão-somente desregrada (ao invés da matrix rimbaudiana fundada sobre o convívio intenso, formal, com a tradição e a ruptura de uma época) feita pelos epígonos de Helder, em Portugal e no Brasil.

E mais (ainda mais), sem descarte da musculatura verbal, conceitual, de que se nutre o autor, desde o primeiro verso, o livro é perpassado por referências mescladas, cambiantes, a Deus e à luminotécnica planetária - “...o videoclipe que transita/, o corpo que transita, / e o nome inominável..." (Ibid.: 604). Assim como se frisa o clamor erótico em linhas enfeixadas por cortes/montagens e associações gradativas envolvidas pelos desdobramentos contígüos de corpo/ terra. Entre o imediatismo vitalista e a autoindagação criadora, entre palavra 
e cosmogonia, A faca não corta o fogo e Ofício cantante se erguem como radicação na finitude (ou da continuidade da arte): "até que Deus é destruido pelo extremo exercicio da beleza sobressalto," (Helder, 2009: 535)

\section{Referências Bibliográficas}

HELDER, Herberto. A faca não corta o fogo. Lisboa: Assírio \& Alvim, 2008. . Ofício cantante. Lisboa: Assírio \& Alvim, 2009. 